\title{
Important Non-Wood Forest Products in Turkey: An Econometric Analysis
}

\author{
Rifat Kurt \\ Bartin University, \\ Faculty of Forestry \\ Bartin, Turkey \\ rkurt@bartin.edu.tr
}

\author{
Selman Karayilmazlar \\ Bartin University, \\ Faculty of Forestry \\ Bartin, Turkey \\ selman@bartin.edu.tr
}

\author{
Yildiz Cabuk \\ Bartin University, \\ Faculty of Forestry \\ Bartin, Turkey \\ ycabuk@bartin.edu.tr
}

\begin{abstract}
Wood resources obtained from forest and non-wood forest products (NWFP) have gained great importance recently as their economic values keeps increasing by the day. In this study, forecasting of Turkish Non-Wood Forest Products such as thyme, bay leaves, salvia and pine nut export amounts was carried out using a linear regression analysis method for the next fifteen years based on the data for the years between 1990 and 2009. Moreover, estimated import values and actual import values from the last years were compered and analyzed. Finally, predictions on future trends were made.
\end{abstract}

Keywords-Regression; Export; Thyme; Bay Leaves; Salvia; Pine Nut

\section{INTRODUCTION}

An important potential of forests is the non-wood forest products (NWFP). Since most of the non-wood forest products in Turkey are subject to traditional small scale utilizations and are called secondary forest products. Even in forests where wood is produced, non-wood forest products are seen as "auxiliary" or "secondary" products. Forests where wood is not produced are considered as low-value or unvaluable forests [1]. Non-wood forest products are defined as all kinds of plant or animal products which grow inside or around a forest, and from which human beings and other living things benefit to meet their needs or to generate income [2]. According to the World Health Organization (WHO) the number of plants used for various purposes around the world is 20,000. And of these plants, whilst 4,000 are widely used as herbal medicine, approximately $10 \%$ is traded [3]. As in all around the world, Non-Wood Herbal Forest Products (NWHFP) make up the most important part of non-wood forest products in Turkey. It is estimated that the number of NWHFP significant in world foreign trade is 150 and the annual foreign trade volume is around 1.1 billion dollars [4]. Today, NWHFP can be used in a wide range of industries such as medical, spices, food, tea, dyes, perfumery and textiles and the marketing of these products could provide significant benefits [5]. Bay leaves, thyme, salvia, pine nut, flower bulbs are among the main byproducts for which Turkey has an export potential. Apart from these products, different faculties continue their research on the species that could be grown in forest bedding [6].

Ways are sought for increasing the contribution of NWFP to the economy, as their contribution is far below their potential. Our country's revenue from NWFP export in the past years is a lot higher than its revenue from wood products. In other words, NWFP make up the $98 \%$ of export revenue from wood products [7]. In the current study, based on the export data of thyme, bay leaves, salvia and pine nut, which have economic precedence, compared to other non-wood forest products in Turkey, for 1990-2009 years, the export numbers for 15 years covering the period between 2010-2024 are estimated with regression analysis.

\section{MATERIALS AND METHODS}

\section{A. Materials}

The material in this study is the export data of thyme, bay leaves, salvia and pine nut between 1990-2009 (Figure 1). The data for the aforementioned products were taken from the Turkish Statistical Institute (TurkStat) and the possible export numbers for 2010-2024 were calculated. The optimal regression models were formed using the SPSS statistical package.

\section{B. Methods}

The main econometric method used in this study is simple linear regression analysis. Regression analysis is a statistical procedure which uses the least squares approach in estimating the relationship between independent variable (s) and dependent variable in developing the estimation model [10]. If the regression analysis involves one dependent and one independent variable, then it is a simple linear regression. Simple linear regression model is solved with the following equation:

$$
Y=\alpha+\beta_{i} X_{i}+\varepsilon_{i}
$$

Where $\alpha_{i}$ and $\beta i$ represent the unknown parameters of the model, $\varepsilon$ i represents the error term, Y represents dependent and $\mathrm{X}$ represents independent variables [11]. In this study, the export numbers of thyme, bay leaves, salvia and pine nut, which are the dependent variables of the study, for 15 years were found based on time series (years) and projection values were calculated using this collected data. Calculation results given in the variance table of the regression model were compared with the coefficients of regression equation, statistical values $\mathrm{F}$ and $\mathrm{t}$ and table values of $\mathrm{F}$ and $\mathrm{T}$ statistical values at the significance level of $\alpha=0.05$ and test was 
performed to find out whether the model is valid and the selected independent variable may be used satisfactorily or not.

\section{FINDINGS}

A. Regression Analysis Results and Projection Values relating to Thyme, Bay leaves, Salvia and Pine Nut Exports

The results of regression analysis on thyme, bay leaves, salvia and pine nut exports indicated that the $r$ Square in the regression model is relatively high in non-wood forest products except pine nut. It was also seen that the F statistical values were valid for all the models or that the relationship between dependent and independent variables was significant at $\alpha=0.05$ significance level (Table I). It should be noted that $r^{2}=0.929$ value for thyme export is a high certainty coefficient. This number indicates that the independent variable explains thyme export almost around $93 \%$ and that the structure of the linear model is appropriate. Similarly, the certainty coefficient of the model set for bay leaves and salvia export (bay leaves: 0.920, salvia: 0.875$)$ are high and provided the required explanation.
And for pine nut, $\mathrm{r}^{2}=0.49$ value is an acceptable certainty coefficient. Because, coefficient of correlation, 0.70 (R), linear relationship between the variables, is about the level 0.60-0.70 recognized in the literature. The results of $\mathrm{t}$ and $\mathrm{F}$ statistical tests of the hypotheses obtained from ANOVA and coefficient tables are given in Table II. The regression models built with thyme, bay leaves, salvia, pine nut are valid and significant. Table III shows the export projection values for thyme, bay leaves, salvia and pine nut. These values are found by putting the independent variable (year) in the regression equation (Table I) formed for each product. In the table, it is estimated that the thyme export which was 11474 tons in 2009 is expected to be 17735 in 2024 with an increase of 54.5\% (1.54 times). And similarly the bay leaves export is expected to see a $38.7 \%$ increase (1.38 times) and reach 12570 tons and salvia exports which was 1544.7 tons is expected to see $100.4 \%$ increase ( 2 times) and reach 3096 tons. Also, pine nut export is estimated to have a $4 \%$ increase compared to 2009 and realize as 2300 tons in 2024 .

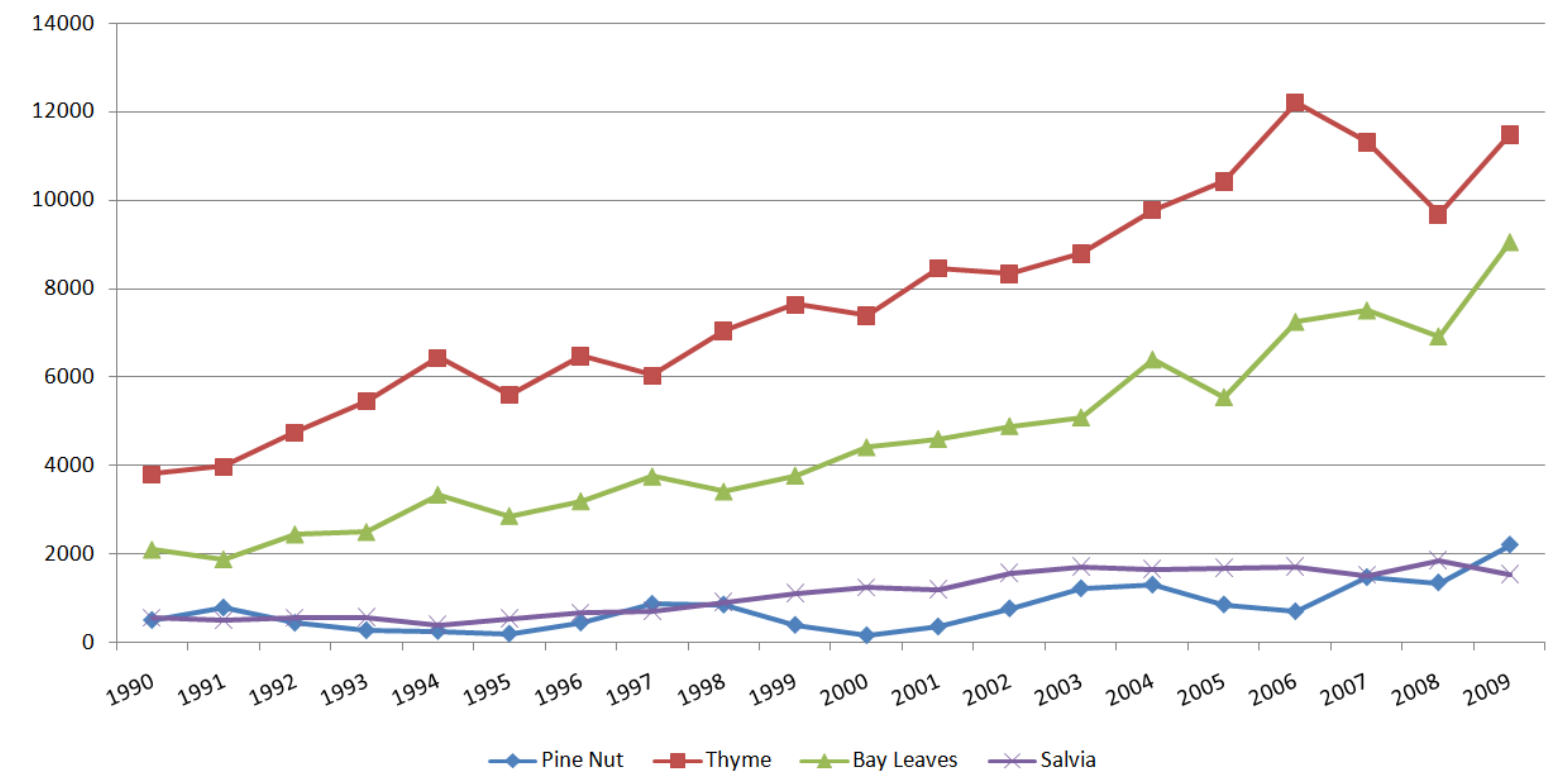

Fig. 1. Export amounts of thyme, bay leaves, salvia and pine nut (in Tonnes).

TABLE I. THE REGRESSION ANALYSIS RESULTS OF NON-WOOD FOREST PRODUCTS

\begin{tabular}{|l|l|l|c|c|c|}
\hline Products & \multicolumn{1}{|c|}{$\mathbf{R}$} & $\boldsymbol{r}^{2}$ & Regression model & Regression equation & Significance \\
\hline Thyme & 0.964 & 0.929 & Linear & $\mathrm{Y}=-806834.211+407.396 \mathrm{x}$ & $\mathrm{p}<0.05$ \\
\hline Bay leaves & 0.959 & 0.920 & Linear & $\mathrm{Y}=-649413.2+327.067 \mathrm{x}$ & $\mathrm{p}<0.05$ \\
\hline Salvia & 0.936 & 0.875 & Linear & $\mathrm{Y}=-160560.158+80.858 \mathrm{x}$ & $\mathrm{p}<0.05$ \\
\hline Pine nut & 0.70 & 0.49 & Linear & $\mathrm{Y}=-123531.883+62.170 \mathrm{x}$ & $\mathrm{p}<0.05$ \\
\hline
\end{tabular}

TABLE II. T AND F TEST RESULTS OF NON-WOOD FOREST PRODUCTS.

\begin{tabular}{|c|c|c|c|c|c|c|c|c|c|}
\hline Products & T calculation & T table & Result & HO & F calculation & F table & Result & HO & Significance \\
\hline Thyme & 15.313 & 2.101 & $\mathrm{~T}$ calculation $>\mathrm{T}$ table & reject & 234.492 & 4.41 & F calculation $>\mathrm{F}$ table & reject & Significant \\
\hline Bay leaves & 14.414 & 2.101 & $\mathrm{~T}$ calculation $>\mathrm{T}$ table & reject & 207.758 & 4.41 & $\mathrm{~F}$ calculation $>\mathrm{F}$ table & reject & Significant \\
\hline Salvia & 11.243 & 2.101 & $\mathrm{~T}$ calculation $>\mathrm{T}$ table & reject & 126.401 & 4.41 & F calculation $>\mathrm{F}$ table & reject & Significant \\
\hline Pine nut & 4.187 & 2.101 & $\mathrm{~T}$ calculation $>\mathrm{T}$ table & reject & 17.534 & 4.41 & $\mathrm{~F}$ calculation $>\mathrm{F}$ table & reject & Significant \\
\hline
\end{tabular}


TABLE 3. EXPORT PROJECTIOONS FOR THYME, BAY LEAVES, SALVIAA AND PINE NUT (INN TONS).

\begin{tabular}{|c|c|c|c|c|}
\hline Years & Thyme & Bay Leaves & Salvia & Pine Nut \\
\hline $\mathbf{2 0 1 0}$ & 12031.749 & 7991.47 & 1964.422 & 1429.817 \\
\hline $\mathbf{2 0 1 1}$ & 12439.145 & 8318.537 & 2045.28 & 1491.987 \\
\hline $\mathbf{2 0 1 2}$ & 12846.541 & 8645.604 & 2126.138 & 1554.157 \\
\hline $\mathbf{2 0 1 3}$ & 13253.937 & 8972.671 & 2206.996 & 1616.327 \\
\hline $\mathbf{2 0 1 4}$ & 13661.333 & 9299.738 & 2287.854 & 1678.497 \\
\hline $\mathbf{2 0 1 5}$ & 14068.729 & 9626.805 & 2368.712 & 1740.667 \\
\hline $\mathbf{2 0 1 6}$ & 14476.125 & 9953.872 & 2449.57 & 1802.837 \\
\hline $\mathbf{2 0 1 7}$ & 14883.521 & 10280.94 & 2530.428 & 1865.007 \\
\hline $\mathbf{2 0 1 8}$ & 15290.917 & 10608.01 & 2611.286 & 1927.177 \\
\hline $\mathbf{2 0 1 9}$ & 15698.313 & 10935.07 & 2692.144 & 2051.517 \\
\hline $\mathbf{2 0 2 1}$ & 16105.709 & 11262.14 & 2773.002 & \\
\hline $\mathbf{2 0 2 2}$ & 16513.105 & 11589.21 & 2934.86 & 2113.687 \\
\hline $\mathbf{2 0 2 3}$ & 16920.501 & 11916.27 & 3015.576 & 2175.857 \\
\hline $\mathbf{2 0 2 4}$ & 17327.897 & 12243.34 & 3096.434 & 2238.027 \\
\hline
\end{tabular}

\section{B. Comparison of projection values and actual values}

Figure 2 shows the comparison of projected and actual export values of non-wood forest products between 2010-2014. In the figure, it is seen that the projected thyme and bay leaves numbers are very close to the projected numbers. It is also seen that the projected salvia values are within acceptable limits. However, it is seen that the actual pine nut numbers are far from the projections and that the export has shown significant decrease. The main factor behind this is the huge crop fall in Bergama district of İzmir province particularly as of 2009 which provides $80 \%$ of Turkey's pine nut production [12]. A disease that occurred in pine nut trees as of 2009 caused to a significant decrease in production and as a result of that, the pines dried out and pine nut crop fell by a significant ratio of $60 \%$. As a result of this, the amount of product exported and the inflow of currency decreased significantly [13-14].
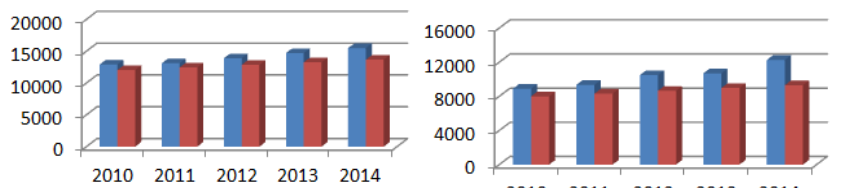

$2010 \quad 2011 \quad 2012 \quad 2013 \quad 2014$

- Thyme observed I- Thyme projected
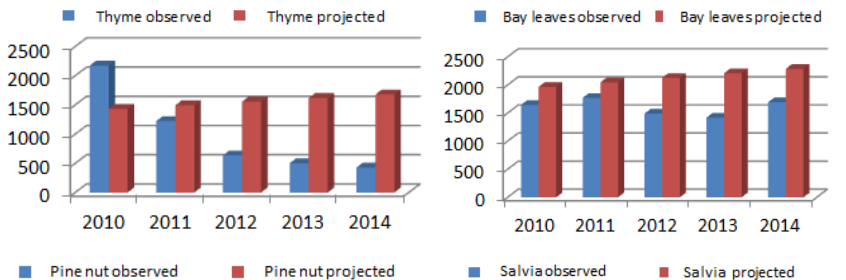

Fig. 1. Projected and actual export numbers between 2010-2014

\section{RESULTS AND CONCLUSION}

When the 15-year export projections (covering 2010-2024) for thyme, bay leaves, salvia and pine nut, which have a significant share in Turkey's non-wood forest product export, was examined, it was seen that the certainty coefficient of the regression model set for thyme, bay leaves and salvia export $\left(\mathrm{r}^{2}\right)$ had such high values as $0.929-0.920-0.875$, respectively and that the linear model set for the projections was appropriate. And certainty coefficient of the model set for pine nut $(0.49)$ had an acceptable correlation based on the literature (0.60-0.70).

In general, it was projected that thyme export which was 11474 tons in 2009 is expected to increase 1.54 times, whilst bay leaves export which was 9063 tons in 2009 is expected to increase 1.38 times and salvia exports which was 1544.7 tons is expected to increase 2 times. Also, pine nut export is expected to have a small increase of 1.04 times compared to 2009 and reach 2300 tons in 2024. When the last 5 years comparison for projected and actual export numbers are analysed, it is seen that the projections for thyme and bay leaves are very close to actual numbers. Also, the projections for salvia could be considered acceptable. However, the projections and actual numbers for pine nut have significant differences. When the reasons of this is examined, it is seen that the reason behind it is not the structure of the model but the huge crop fall in Bergama district of İzmir province which provides $80 \%$ of Turkey's pine nut production. Due to a disease seen in pines in this area as of 2009 , there has been a significant fall in productivity and a $60 \%$ fall in pine nut crops. In addition to their contribution to development and economy, the use of non-wood forest products in medicine and pharmaceutical industry in today's world in which GM (genetically modified organism) foods are discussed, are highly important in terms of food safety due to their organic structure and their small interaction with chemicals. And these NWFPs are becoming more and more prominent. Turkey ranks the 21 st in the export of non-wood forest products, however, the country ranks at the top of the list in the export of some NWFPs. Still it is obvious that non-wood forest products, which have a rich source in terms of plant diversity, wild life resources and endemic species, are not given due consideration and do not deserve its current condition.

In order to increase the export of non-wood forest products in Turkey the inventory and expansion of prominent products should be determined and the best time to harvest those products should be determined to ensure maximum 
productivity. Considering that although there has been an increase in the export numbers of thyme and bay leaves in recent years, the fact that their unit prices fell necessitates that pricing decisions during the marketing phase should be taken in a healthier manner as soon as possible.

In addition, during secondary wood raw material production and forestation, necessary measures shall be taken in order not to damage these resources. Besides, in order to harvest these products in the following years, they should be harvested without damaging and the factories where they are processed should be equipped with the necessary technology. As stated in earlier research, by attaching the deserved importance to non-wood forest products, more contribution will be provided by these products to the economy of the country compared to the wood raw material and with efficient management, damage to the forests in the country will be prevented.

\section{REFERENCES}

[1] R. Kurt, Y. Cabuk, S. Karayilmazlar, "Türkiye ve Dünya Yuvarlak Odun ve Odun Dış1 Orman Ürünlerinin Üretim, Dış Ticaret ve Ekonomik Potansiyel Analizi” Bartın Üniversitesi, Orman Fakültesi Dergisi, Cilt: 13, Say1: 20, s.1-9, 2011 a

[2] U. Geray, Ulusal Cevre Eylem Planı, Orman Kaynakları Yönetimi, DPT yayınları, ISBN:975-19-1917-7, Ankara, 115 s, 1998

[3] O. Balci, “Odun Dışı Bitkisel Ürünler”, Bitkisel Ürünler Şube Müdürlüğü, Uluslararası Orman Yıl1, www.ogm.gov.tr
[4] DPT "VIII Beş Yıllık Kalkınma Planı Ormancılık Özel İhtisas Komisyon Raporu”, Ankara, 2001

[5] R. Kurt, Y. Cabuk, S. Karayilmazlar, "Foreign Trade Analysis of Spices and Spices Derivates as Non-Wood Forest Products of Turkey", 2nd International Non-Wood Products Symposium, Isparta, TURKEY, pp. 23-31, 8-10 September 2011,

[6] B. Ors, “Orman Ürünlerimiz ve Orman Köylüsüne Katkıları”, Kozalak, TC Orman Bakanlığı Gazetesi, Yı1:2, Sayı:14, Ekim 1999

[7] M. Konukcu, "Ormanlar ve Ormancılı̆̆ımız, Faydaları", İstatistiki Gerçekler, DPT Yayın No: 2630, Eylül, 2001

[8] Turkstat, "Turkish Statistical Institute (TurkStat)", Ankara, www.tuik.gov.tr

[9] R. Kurt, Türkiye Odun Dışı Orman Ürünlerinin Mevcut Durumu ve Dış Ticaret Analizi, Yüksek Lisans Tezi, Bartın Üniversitesi, Bartın, 2011

[10] Y. Cabuk. S. Karayilmazlar, R. Kurt, S. M. Onat, "Estimating Future Development of the Turkish Plywood Sector By The Use Of Models Affecting This Forest Industry Sector", International Journal of the Physical Sciences, Vol. 6, No. 4, pp. 808-818, 2011

[11] O. Unver, H. Gamgam, Uygulamalı İstatistik Yöntemler. İkinci Bask1, Siyasal Kitabevi, Ankara, 1996

[12] A. Alp, "Çam Fıstığında Düşen Rekolte Kozak Üzümünü Öne Çıkardı", Ekonomi,http://www.dunya.com/ekonomi/ekonomi-diger/cam-istigindadusen-rekolte-kozak-uzumunu-one-cikardi-199122h.htm,

[13] E. Seyirden, "Çam Fıstığı Rekoltesi Üreticiyi De İhracatçıyı da Üzdü”, http://ticaretgazetesi.com.tr/haberler cam fistigi rekoltesi ureticiyi_de ihracatciyi_da_uzdu-1-1-sayfa_id-66̆-id-103440, 2016

[14] URL-1 "Çam Fistığ1 Verimini Düşüren Böcek Bulundu”, http://www.yeniasir.com.tr/kenthaberleri/2015/01/13/cam-fistigiverimini-dusuren-bocek-bulundu, 2016 